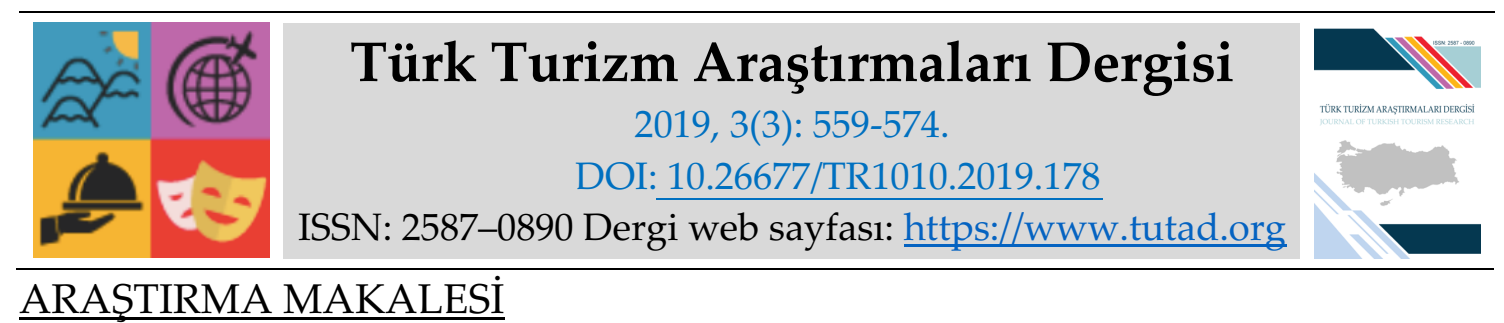

\title{
Turizm Rehberliği Eğitimi Alan Öğrencilerin Yaşam Boyu Öğrenme Eğilimlerinin Belirlenmesi*
}

Doç. Dr. Ahmet KÖROĞLU, Balıkesir Üniversitesi, Turizm Fakültesi, Turizm İşletmeciliği Bölümü, Balıkesir, e-posta: akoroglu@balikesir.edu.tr

ORCID: https://orcid.org/0000-0002-6694-4667

Doç. Dr. Özlem KÖROĞLU, Balıkesir Üniversitesi, Turizm Fakültesi, Turizm Rehberliği Bölümü, Balıkesir, e-posta: okoroglu@balikesir.edu.tr ORCID: https://orcid.org/0000-0002-3974-6120

İpek ASMADİLİ, Yüksek Lisans Öğrencisi, Balıkesir Üniversitesi, Sosyal Bilimler Enstitüsü, Turizm Rehberliği Anabilim Dalı, Balıkesir, e-posta: asmadili.ipek@gmail.com ORCID: https://orcid.org/0000-0001-8000-3399

Öz

Turizm rehberliği öğrencilerinin bireysel ve mesleki açıdan gelişimlerini sağlayıp iyi bir rehber olabilmeleri için yaşam boyu öğrenmenin gerekliliklerini yerine getirmeleri ve motivasyona sahip olmaları gerekmektedir. Bu araştırmanın amacı, turizm rehberliği eğitimi alan öğrencilerin yaşam boyu öğrenme eğilimlerinin belirlenmesidir. Araştırmanın örneklemini Balıkesir Üniversitesi Turizm Fakültesi Turizm Rehberliği bölümünde öğrenim görmekte olan 323 öğrenci oluşturmaktadır. Araştırmada anket yöntemiyle elde edilen veriler, frekans analizi, güvenirlik analizi, açımlayıcı faktör analizi, aritmetik ortalama ve standart sapma değerlerinin analizi, bağımsız grup $\mathrm{t}$ testi ve tek yönlü varyans analizi (ANOVA) kullanılarak değerlendirilmiştir. Araştırmanın sonucunda turizm rehberliği eğitimi alan öğrencilerin yaşam boyu öğrenme eğilimlerinin yüksek olduğu, ayrıca öğrencilerin demografik özellikleri ile yaşam boyu öğrenme eğilimleri arasında da farklılıklar olduğu tespit edilmiştir.

*Bu çalışma, 29-30 Nisan 2019 tarihleri arasında Adnan Menderes Üniversitesi Turizm Fakültesi (Aydın/Kuşadası) ev sahipliğinde düzenlenen II. Turizm Rehberliği Kongresi'nde sözlü bildiri olarak sunulmuştur.

Anahtar Kelimeler: Turizm Rehberliği, Turizm Rehberliği Eğitimi, Turizm Rehberliği Öğrencileri, Yaşam Boyu Öğrenme Eğilimi.

Makale Gönderme Tarihi: 19.05.2019

Makale Kabul Tarihi: 05.07.2019

\section{Önerilen Atıf:}

Köroğlu, A., Köroğlu, Ö. ve Asmadili, İ. (2019). Turizm Rehberliği Eğitimi Alan Öğrencilerin Yaşam Boyu Öğrenme Eğilimlerinin Belirlenmesi, Türk Turizm Araştırmaları Dergisi, 3(3): 559-574. (C) 2019 Türk Turizm Araştırmaları Dergisi. 


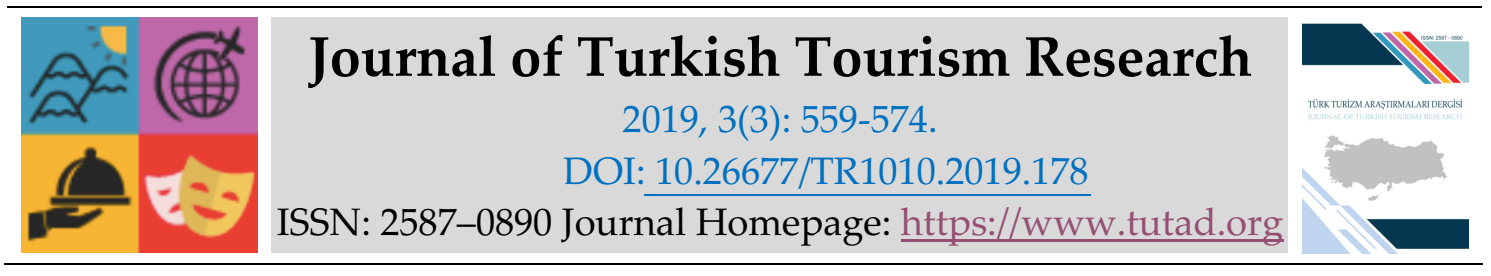

RESEARCH PAPER

\title{
Determination of Living Learning Tendencies of Students with Tourism Guiding Education
}

Associate Prof. Dr. Ahmet KÖROĞLU, Balıkesir University, Faculty of Tourism, Department of Tourism Management, Balıkesir, e-mail: akoroglu@balikesir.edu.tr

ORCID: https://orcid.org/0000-0002-6694-4667

Associate Prof. Dr. Özlem KÖROĞLU, Balıkesir University, Faculty of Tourism, Department of Tourism Guidance, Balıkesir, e-mail: okoroglu@balikesir.edu.tr

ORCID: https://orcid.org/0000-0002-3974-6120

İpek ASMADİLI, Graduate Student, Balıkesir University, Institute of Social Sciences, Department of Tourism Guidance, Balıkesir, e-mail: asmadili.ipek@gmail.com

ORCID: https://orcid.org/0000-0001-8000-3399

\begin{abstract}
Tourism guidance students need to fulfill the requirements of lifelong learning and have this motivation in order to provide their personal and professional development and to be a good guide. The aim of this study is to determine the lifelong learning tendencies of the students who have received tourism guidance education. The sample of the study consisted of 323 students studying at Balıkesir University, Tourism Faculty, Department of Tourism Guidance. The data obtained by the survey method were evaluated by frequency analysis, reliability analysis, exploratory factor analysis, analysis of arithmetic mean and standard deviation values, independent group $t$ test and one-way analysis of variance (ANOVA). As a result of the research, it was determined that the lifelong learning tendencies of the students receiving tourism guidance education were high and there were also differences between the students' demographic characteristics and lifelong learning tendencies.
\end{abstract}

Keywords: Tourism Guidance, Tourism Guidance Education, Tourism Guidance Students, Lifelong Learning Tendency.

Received: 19.05.2019

Accepted: 05.07.2019

Suggested Citation:

Köroğlu, A., Köroğlu, Ö. and Asmadili, İ. (2019). Determination of Living Learning Tendencies of Students with Tourism Guiding Education, Journal of Turkish Tourism Research, 3(3): 559-574.

(C) 2019 Türk Turizm Araştırmaları Dergisi. 


\section{Gíriş}

Turizm sektöründe kültürlerarası etkileşimi ve gelişimi sağlayabilmek için ziyaretçi ve ziyaret edilen toplum arasındaki boşluğu dolduracak ve toplumların gelişimine destek sağlayacak olan kişiler turist rehberleridir (Avcıkurt, 2017). Rehber, bilgi birikimi ve davranışları ile toplum ve ülkeyle ilgili bilgi ve izlenim vermektedir. Ülkeyi ve toplumu farklı kültürel toplumlardan gelen ziyaretçilere karşı temsil etmek çok büyük bir sorumluluktur (Temizkan, 2005). Turist rehberlerinin turistin memnuniyetini sağlamak ve beklentilerini karşılamak için yerine getirdiği; liderlik, bilgi sağlayıcılık, aracılık, aktörlük, öğretmenlik, organizatörlük ve arabuluculuk gibi rolleri bulunmaktadır (Tetik, 2012). Bu rollerin tamamını yerine getirebilmek için turist rehberlerinin her alanda belirli bir birikime sahip olmaları gerekmektedir. Günümüzde sürekli olarak değişen ve güncelliğini kaybeden bilgiler doğrultusunda turist rehberi adaylarının da kendilerini sürekli yenileme zorunluluğu ortaya çıkmakta, onları her gün öğrenme gerekliliğine itmektedir. İş dünyasında artan rekabetle birlikte işgörenlerin niteliklerinin arttırılması, özellikle hızla gelişen turizm sektöründe önem arz etmektedir (Üzümcü vd., 2015). Günümüzdeki eğitim kurumlarında edinilen bilgi ve beceriler eskisi kadar uzun süreli ve geçerli olamamaktadır. Geçmiş zamanlarda belirli bir meslek sahibi olan bireylerin hayatları boyunca aynı işi aynı bilgi ile sürdürebildikleri görülmektedir. Fakat günümüz için bu durum pek mümkün görünmemektedir (Ayra ve Kösterelioğlu, 2015: 18). Turist rehberliği mesleği de aynı bilgilerle yıllar boyunca aynı işin yapılabileceği bir özellik taşımamaktadır. Bu nedenle turizm rehberliği eğitimi alan öğrenciler de çağın gereği olan bilgi ve becerileri hayata geçirmek için kendi kendilerine öğrenmeyi başarabilmelidirler. Ayrıca turizm rehberliği öğrencilerinin bireysel ve mesleki açıdan gelişimlerini sağlayıp iyi bir rehber olabilmeleri için yaşam boyu öğrenmenin gerekliliklerini yerine getirmeleri ve bu motivasyona sahip olmaları gerekmektedir. Bu bağlamda, bu araştırmanın amacı, turizm rehberliği eğitimi alan öğrencilerin yaşam boyu öğrenme eğilimlerinin belirlenmesidir. Çalışmanın ana problemini turizm rehberliği eğitimi alan öğrencilerin yaşam boyu öğrenme eğilimlerinin düzeylerinin belirlenmesi oluşturmaktadır.

\section{KAVRAMSAL ÇERÇEVE}

Günümüzde iş hayatında, teknoloji ve bilimde, insanların birbirleriyle iletişiminde yaşanan hızlı değişimler sebebiyle yaşam boyu öğrenme dünya çapında ilgi gören bir kavram haline gelmiş (Erdamar, 2011: 235), örgün eğitimin, toplumun ihtiyaçlarına yanıt veremediğinin görülmesi ve yetersizliğinin fark edilmesiyle de kolayca kabullenilmiştir. Fakat bu anlamda yaşam boyu öğrenme örgün eğitimi hiçe saymak değil, yalnızca örgün eğitimin eksik yerlerinin sonradan tamamlanması veya önceleri ortaya çıkarılmamış yeteneklerin keşfedilmesi olarak kabul görmektedir (Güleç vd., 2012: 37). Yaşam boyu öğrenme, bir yandan mevcut olanı daha görünür, esnek, entegre ve etkili kılarken diğer yandan yeni öğrenme süreçleri, ürünleri ve ortamları geliştirmeyi gerektirmektedir (European Commission, 2002). Yaşam boyu öğrenme kavramı kısaca; yaşam boyunca, gönüllü ve motivasyona dayalı olarak kişisel veya mesleki sebeplerle yeterliliğin arttırılmasıdır (Goverment of Irland, 2000). Bir başka ifadeyle yaşam boyu öğrenme; bireyin yaşamı boyunca bilgisini, becerilerini, yeterliliklerini, bireysel, sosyal ya da mesleki olarak geliştirmeyi amaçlayan tüm etkinlikler olarak tanımlanmaktadır (Günüç vd., 2012: 310). Yaşam boyu öğrenme kavramını Samancı ve Ocakçı (2017), "insan yaşamının başlangıcından sonuna kadar devam eden bir süreçtir. Bu süreçte yaşam boyu öğrenme, örgün eğitimin getirdiği yaş ve mekân sinırına bağhl kalmaksızın, bireyin eğitim yoluyla kazandığı her türlü bilgi, beceri, tutum ve davranışlardır" şeklinde tanımlamaktadırlar. Yaşam boyu öğrenme kavramını açıklamaya ve kavramın önemine yönelik birçok çalışmaya rastlanmaktadır. Aspin ve Chapman (2010) yapmış oldukları çalışmada yaşam boyu öğrenme kavramının birkaç versiyonunu gözden geçirmekte ve 
yaşam boyu öğrenmenin ana hatlarını ortaya koymaktadırlar. Tuschling ve Engemann (2006) çalışmalarında yaşam boyu öğrenme kavramının temeline ve toplum açısından önemine değinmektedirler. Bunların yanı sıra Dunlap (2003) yaptığı çalışmada günümüzün sürekli değişim ve yenilikçi ikliminde, insanları yaşam boyu öğrenmeye hazırlamak gereği üzerinde durmaktadır.

Literatürde yaşam boyu öğrenme kavramının turizmle ilişkilendirilerek gerçekleştirildiği yalnızca bir çalışmaya rastlanmaktadır. Bu çalışma Aksoy'un (2008) "yaşam boyu öğrenme teriminin kavramsallaştırılması ile otel işletmelerindeki yaşam boyu öğrenme ve kariyer rehberliği ilkeleri doğrultusunda yürütülen öğrenme faaliyetlerinin, iş görenlerin istihdam edilebilirliklerine olan katkılarmı ortaya çıkarmak" amacıyla gerçekleştirdiği çalışmadır. Araştırmanın sonuçlarına göre çalışanların hizmet öncesi eğitiminin yanında katıldıkları yaşam boyu öğrenme faaliyetlerinin istihdam edilebilirlikte etkili olduğu görülmektedir. Ayrıca, yaşam boyu öğrenme faaliyetlerinin, çalışanların işletmeye bağlılıklarının artmasında ve daha kaliteli mal ve hizmet üretmede stratejik bir yol olarak görülmeleri gerektiği üzerinde durulmuştur.

Yaşam boyu öğrenme ile ilgili çalışmaların genellikle üniversite öğrencileri üzerinde (Atacanl,, 2007; Diker Coşkun, 2009; Diker Coşkun ve Demirel, 2012; Evin Gencel, 2013; Karakuş, 2013; Kozikoğlu, 2014; Gür Erdoğan, 2014; Sarıgöz, 2015; Adabaş, 2016; Boztepe, 2017; Horuz, 2017; Mülhim, 2018; Kangalgil ve Özgün, 2018) yapıldığ1 görülmektedir. Örneğin Diker Coşkun (2009) tarafından yapılan üniversite öğrencilerinin yaşam boyu öğrenme eğilimlerinin farklı değişkenler açısından incelendiği çalışmada; üniversite öğrencilerinin yaşam boyu öğrenme eğilimlerinin düşük olduğu belirlenmiştir. Diker Coşkun ve Demirel'in (2012) yine aynı amaçla yaptıkları çalışmada, öğrencilerin yaşam boyu öğrenme faaliyetlerine katılmada isteksiz oldukları, bu faaliyetleri sürdürmede zorlandıkları ve yaşam boyu öğrenme için önemli olan meraklılığın öğrencilerde mevcut olmadığı sonuçlarına ulaşılmıştır. Horuz ise (2017) mesleki eğitim merkezi öğrencilerinin yaşam boyu öğrenme eğilimlerini incelemek amacıyla yaptığ çalışmada öğrencilerin yaşam boyu öğrenme eğilimlerinin yüksek olduğu sonucuna ulaşmıştır.

Yaşam boyu öğrenmenin farklı değişkenlerle ilişkilerinin incelendiği çalışmalara bakıldığında ise Mülhim'in (2018) yaptığı çalışmada, toplumların akademik ve sosyal alanda kalkınması için yenilikçiliğin ve bireysel olarak yaşam boyu öğrenmenin gerekliliği üzerinde durarak, Beden Eğitimi ve Spor Yüksekokulu öğrencilerinin bireysel yenilikçilik düzeyleri ve yaşam boyu öğrenme eğilimlerini belirleyip aralarındaki ilişkiyi ortaya çıkarmayı amaçlamıştır. Araştırmanın sonucunda öğrencilerin yenilikçilik düzeylerinin yüksek olduğu ve bunun da yaşam boyu öğrenme eğilimlerini etkilediği sonucuna ulaşılmıştır. Gür Erdoğan (2014) tarafından yapılan öğretmen adaylarının yaşam boyu öğrenme eğilimlerinin; öğrenme yeterlilikleri, akademik branşlarından memnun olmaları ve kariyer geliştirme arzuları ile ilişkisini ve üzerindeki etkilerini belirlemeyi amaçladığı çalışmanın sonucunda, öğretmen adaylarının yaşam boyu öğrenme eğilimlerinin yüksek olduğu görülmektedir. Ayrıca akademik branş memnuniyetlerinin yaşam boyu öğrenme eğilimleri üzerinde etkili olmadığı ve kariyer geliştirme arzularının da orta düzeyde etkili olduğu sonuçlarına ulaşılmıştır. Boztepe (2017) tarafından yapılan çalışmada öğretmen adaylarının yaşam boyu öğrenme ve iletişim memnuniyetleri arasındaki ilişkisi incelenmiş, yaşam boyu öğrenme ile iletişim memnuniyetleri arasında anlamlı bir ilişki bulunmuştur. Yaşam boyu öğrenme eğilimlerinin bazı meslek gruplarında belirlenmesine yönelik çalışmalarda genellikle öğretmenler üzerinde durulduğu görülmektedir. Örneğin, Yaman (2014) öğretmenlerin yaşam boyu öğrenme eğilimlerini belirlemek amacıyla bir çalışma yürütmüştür. Bu çalışmanın sonucunda öğretmenlerin yaşam boyu öğrenme eğilimlerinin yüksek düzeyde olduğu tespit edilmiştir. Aynı şekilde Ayaz (2016) tarafından yapılan çalışmanın sonucunda da öğretmenlerin yaşam boyu öğrenme eğilimlerinin yüksek düzeyde olduğu ortaya çıkmıştır. Ayra ve Kösterelioğlu'nun (2015) öğretmenlerin yaşam 
boyu öğrenme eğilimleri ile mesleki öz yeterlik algıları arasındaki ilişkinin belirlenmesi amacıyla gerçekleştirdikleri çalışmada, öğretmenlerin yaşam boyu öğrenme eğilimleri ile mesleki öz yeterlik algılarının iyi düzeyde olduğu görülmektedir. Ayrıca öğretmenlerin, yaşam boyu öğrenme ve öz yeterlik algıları arasında anlamlı bir ilişki olduğu belirlenmiştir.

\section{YÖNTEM}

$\mathrm{Bu}$ araştırmanın amacı turizm rehberliği eğitimi alan öğrencilerin yaşam boyu öğrenme eğilimlerinin belirlenmesidir. Turizm rehberliği eğitimi alan öğrencilerin yaşam boyu öğrenme eğilimlerinin hangi düzeyde olduğunun belirlenmesi bu çalışmanın ana problemini oluşturmaktadır. Ayrıca araştırmada yaşam boyu öğrenme eğiliminin çeşitli değişkenlerle (cinsiyet, yaş, sınıf düzeyi, bölüm seçiminde etkili olan durum, bölümden memnun olma durumu, mesleği yapmayı düşünme durumu ve iş yaşamında başarılı olacağına dair duyulan inanç) ilişkisinin ortaya konması da amaçlanmıştır.

Araştırmanın evrenini, Balıkesir Üniversitesi Turizm Fakültesi Turizm Rehberliği bölümünde 2018-2019 eğitim öğretim yılında birinci, ikinci, üçüncü ve dördüncü sinıflarda öğrenim görmekte olan 680 öğrenci oluşturmaktadır. Araştırmaya başlamadan önce Balıkesir Üniversitesi Turizm Fakültesi Dekanlığından gerekli izinler alınmıştır. Verilerin toplanmasında zaman ve maliyet kısıtları dikkate alındığından kolayda örnekleme yöntemi tercih edilmiş, ulaşılabilen ve anketi yanıtlamayı kabul eden öğrenciler örneklemeye dahil edilmiştir (Altunışık vd., 2004). Araştırmaya katılımda gönüllülük esas alınmış, veri toplama aracını gönüllü olarak yanıtlayan 326 öğrenci ile araştırma gerçekleştirilmiştir. Ancak toplanan 326 anket formundan üç tanesi eksik veri içerdiğinden dolayı değerlendirmenin dışında bırakılmış ve 323 anket formu dikkate alınarak analizler gerçekleştirilmiştir. Altunışık vd., göre (2004: 125), evren büyüklüğü 700 olan araştırmanın örnekleminin 248 olması yeterli görülmektedir. Bu araştırmaya katılan öğrenci sayısı ise $n=323^{\prime}$ tür. Dolayısıyla araştırmanın örnekleminin evreni temsil ettiği ve ortaya çıkan sonuçların evrene genellenebilmesi açısından yeterli olduğu düşünülmektedir.

Turizm rehberliği eğitimi alan öğrencilerin yaşam boyu öğrenme eğilimlerinin belirlenmesi amaçlanan bu çalışmada birincil verilerin elde edilmesi maksadıyla en çok başvurulan yöntemlerden biri olan anket tekniği kullanılmıştır. Öncelikle konuyla ilgili yerli ve yabancı yazın taraması yapılarak anket formu oluşturulmuştur. Anket formu iki bölümden oluşmaktadır. Formun birinci bölümünde turizm rehberliği bölümü öğrencilerinin sosyo-demografik özelliklerinin belirlenmesine yönelik sorulan yedi soru yer almaktadır. Bu sorularla öğrencilerin cinsiyeti, yaşı, sınıfı, bölümü seçmede etkili olan durumu, seçilen bölümden memnun olma durumu, rehberlik mesleğini yapma isteği ve iş yaşamında başarılı olacağına dair duyulan inancı belirlenmeye çalışılmaktadır. Anket formunun ikinci bölümünde ise "Yaşam Boyu Öğrenme Eğilimlerini Belirleme Ölçeği" yer almaktadır. Yaşam Boyu Öğrenme Eğilimlerini Belirleme Ölçeği, Diker Coşkun (2009) tarafından çeşitli bölümlerde öğrenim gören üniversite öğrencilerinin yaşam boyu öğrenme eğilimlerinin belirlenmesi amacıyla geliştirilmiştir. Bu çalışmada da Diker Coşkun (2009) tarafından geliştirilen ve diğer çalışmalarda da kullanılan (Haseski vd., 2014; Arslan vd., 2016; Çam ve Üstün, 2016; Yılmaz ve Beşkaya, 2018) ölçekten yararlanılmıştır. Yaşam Boyu Öğrenme Eğilimlerini Belirleme Ölçeği, altılı Likert tipinde (Çok Uyuyor, Kısmen Uyuyor, Çok Az Uyuyor, Çok Az Uymuyor, Kısmen Uymuyor, Hiç Uymuyor) ve 27 ifadeden oluşan bir ölçektir. Diker Coşkun (2009) tarafından, ölçeğin güvenirliğinin test edilmesi amacıyla yapılan analiz sonucunda ölçeğin Cronbach alpha iç tutarlılık katsayısı 0,89 olarak bulunmuştur. Ölçek, yaşam boyu öğrenme eğilimlerini olumlu ve olumsuz yönde niteleyen dört farklı alt boyuttan oluşmaktadır. Birinci faktör "motivasyon" faktörünü (6 ifade), ikinci faktör "sebat" faktörünü (6 ifade), üçüncü faktör "öğrenmeyi düzenlemede yoksunluk" 
faktörünü (6 madde) ve dördüncü faktör "merak yoksunluğu" faktörünü (9 madde) açıklamaktadır (Diker Coşkun, 2009; Diker Coşkun ve Demirel, 2012: 112). Yaşam boyu öğrenme eğilimlerini belirleme ölçeğindeki olumlu cümleler "Hiç Uymuyor" seçeneğinden "Çok Uyuyor" seçeneğine doğru 1,2,3,4,5,6 şeklinde puanlanırken olumsuz cümleler de bunun tam tersi bir yol izlenerek "Hiç uymuyor" seçeneğinden "Çok uyuyor" seçeneğine doğru 6,5,4,3,2,1 şeklinde puanlanmıştır (Çam ve Üstün, 2016: 463). Yaşam boyu öğrenme eğilimlerini belirleme ölçeğinden alınabilecek en düşük puan 27 (27x1), en yüksek puan ise 162'dir (27X6) (Diker Çoşkun ve Demirel, 2012). Ayrıca Diker Coşkun (2009) ölçekten alınabilecek ortanca puanı (27x3,5) 94,5 olarak hesaplamışlardır. Ölçekten alınan puanın ortanca puanın üzerinde olması katılımcıların yaşam boyu öğrenme eğilimlerinin yüksek olduğunu göstermektedir.

\section{BULGULAR VE YORUM}

Araştırmada öncelikle katılımcıların sosyo-demografik özellikleri incelenmiştir. Elde edilen verilere göre katılımcıların $\% 52,9^{\prime}$ u erkek ve \%47,1'i kadındır. Katılımcıların \%58,5'inin 20-22 yaş aralığında ve \%27,6'sının 17-19 yaş aralığında olduğu saptanmıştır. Katılımcıların \%30,3'ü birinci sınıf, \%26,3'ü dördüncü sınıf, \%22,6'sı ikinci sınıf ve \%20,7'si üçüncü sinıftır. Katılımciların $\% 49,2$ 'si, turizm rehberliği bölümünü kısmen isteyerek seçtiklerini, \%40,6's1 ise isteyerek seçtiklerini belirtmişlerdir. Katılımcıların \%10,2'si turizm rehberliği bölümünü istemeyerek seçtiklerini ifade etmişlerdir. Katılımcıların seçtikleri bölümden memnun olma durumlarına bakıldığında ise \%48,6'sının seçtikleri bölümden memnun oldukları, \%17,6'sının kararsız oldukları, \%15,8'inin çok memnun oldukları ve \%4,3'ünün hiç memnun olmadığı tespit edilmiştir. Katılımcıların \%41,5'i, mezun olduklarında rehberlik mesleğini yapmayı düşündüklerini, \%37,5'i rehberlik mesleğini yapmada kararsız olduklarını ve \%20,4'ü rehberlik mesleğini yapmayı düşünmediklerini ifade etmişlerdir. Katılımcıların \%64,1'i iş yaşamında başarılı olacaklarına dair bir inanca sahip olduğunu, \%28,5'i bu konuda kararsız olduğunu ve \%7,1'i iş yaşamında başarılı olacaklarına dair bir inanca sahip olmadıklarını belirtmişlerdir.

Tablo 1'de Yaşam Boyu Öğrenme Eğilimlerini Belirleme Ölçeğinin faktör yapısını belirlemek amacıyla yararlanılan açımlayıcı faktör analizinin sonuçları yer almaktadır. Yapılan faktör analizi sonucunda faktör yükü 0,30'un altında kalan "Kişisel gelişimim için harcayacağım zaman sevdiklerimle birlikte geçirmeyi tercih ederim." ve "Sadece merak ediyorum diye bir konuyu öğrenmek için vakit ayırmam." ifadeleri ölçekten çıkarılmıştır. Bundan sonraki gerçekleştirilen analizlere bahsi geçen iki ifade dâhil edilmemiş, bu ölçekteki ifade sayısı 25'e indirilmiştir. Yaşam Boyu Öğrenme Eğilimlerini Belirleme Ölçeğinin açımlayıcı faktör analizi, 25 ifade üzerinden tekrar yapılmıştır. İlk olarak verilerin faktör analizine uygunluğunu test etmek amacıyla Kaiser-Meyer-Olkin örneklem değeri hesaplanmış ve Barlett's Sphericity testi yapılmıştır. Kaiser-Meyer-Olkin örneklem değeri 0,913 iken Barlett's Sphericity testi sonucu da anlamlılık göstermektedir $(\mathrm{p}=0,000<0,05)$. Bu sonuçlar verilere yönelik faktör analizinin uygulanabilir olduğunu ifade etmektedir. Analizler sonucuna göre 25 değişken 4 faktör altında toplam varyansın \%57,206'sı açılanmaktadır. Buna göre Yaşam Boyu Öğrenme Eğilimlerini Belirleme Ölçeğinin özdeğeri 1'den büyük ve 4 bileşenli bir yapısı ortaya çıkmıştır. İlk faktörün tanımladığı fark yüzdesi 33,340 düzeyindedir ve 7 maddeden oluşmaktadır. Bu faktör orijinal ölçekte olduğu gibi "merak yoksunluğu" olarak adlandırılmıştır. "Merak Yoksunluğu" faktörünün güvenilirlik testi sonucunda Cronbach Alpha katsayısının 0,874 olduğu görülmektedir. İkinci faktörün tanımladığı fark yüzdesi 13,492 düzeyindedir ve 6 maddeden oluşmaktadır. Bu faktör orijinal ölçekte olduğu gibi "sebat" olarak adlandırılmıştır. "Sebat" faktörünün Cronbach Alpha katsayısı 0,839 olarak görülmektedir. Üçüncü faktörün tanımladığı fark yüzdesi 5,853 
düzeyindedir ve 6 maddeden oluşmaktadır. Bu faktör orijinal ölçekte olduğu gibi "motivasyon" olarak adlandırılmıştır.

Tablo 1. Yaşam Boyu Öğrenme Eğilimlerini Belirleme Ölçeğinin Açımlayıcı Faktör Analizi Sonuçları

\begin{tabular}{|c|c|c|c|c|c|}
\hline & MADDELER & F1 & F2 & F3 & F4 \\
\hline \multirow{7}{*}{ 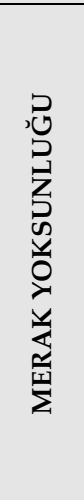 } & $\begin{array}{l}\text { 25. Zorunlu haller dışında yeni şeyler öğrenmek için çaba harcamak yerine, } \\
\text { hobilerimle ilgilenmeyi tercih ederim. }\end{array}$ & 0,753 & & & \\
\hline & $\begin{array}{l}\text { 19. Zorunlu değilsem (sınav, proje vb için) zamanımı araştırma yaparak } \\
\text { kaybetmek istemem. }\end{array}$ & 0,727 & & & \\
\hline & $\begin{array}{l}\text { 26. Eğer beni maddi olarak sıkıntıya düşürecekse yeni bilgi ve beceriler } \\
\text { öğrenmek için çaba harcamak istemem. }\end{array}$ & 0,706 & & & \\
\hline & $\begin{array}{l}\text { 21. Öğrendiğim konudan sorumlu değilsem (sınav vb. olmayacaksam) } \\
\text { eksiklerimi tamamlamak için çaba harcamayı gerekli görmem. }\end{array}$ & 0,692 & & & \\
\hline & 24. Kütüphanelerin sıkıcı yerler olduğunu düşünürüm. & 0,688 & & & \\
\hline & $\begin{array}{l}\text { 22. Zorunlu olmadıkça sadece yeni şeyler öğreneceğim diye kurs ve seminerlere } \\
\text { katılmanın bana zaman kaybettireceğini düşünürüm. }\end{array}$ & 0,685 & & & \\
\hline & $\begin{array}{l}\text { 27. Sürekli yeni bilgi ve beceriler öğrenmek zorunda hissetmek beni rahatsız } \\
\text { eder. }\end{array}$ & 0,647 & & & \\
\hline \multirow{6}{*}{ 造 } & $\begin{array}{l}\text { 12. Öğrendiğim konu zor ve karmaşık da olsa onu en iyi biçimde öğrenmek için } \\
\text { çabalarım. }\end{array}$ & & 0,748 & & \\
\hline & 9. Yeni bilgi ve beceriler öğrenebilmek için özel harcamalarımdan pay ayırırım. & & 0,706 & & \\
\hline & $\begin{array}{l}\text { 10. Herhangi bir zorunluluk olmadan yeni bilgi ve beceriler kazanmak için } \\
\text { kendiliğimden çabalarım. }\end{array}$ & & 0,690 & & \\
\hline & $\begin{array}{l}\text { 8. Programım yoğun olsa bile, kendi kendime yeni bilgi ve beceriler öğrenmek } \\
\text { için fırsatlar yaratırım. }\end{array}$ & & 0,675 & & \\
\hline & $\begin{array}{l}\text { 11. Öncelikli hedeflerimi gerçekleştirirken bunlarla ilgili olmayan yeni bilgi ve } \\
\text { beceriler de kazanmaya çalışırım. }\end{array}$ & & 0,650 & & \\
\hline & $\begin{array}{l}\text { 7. Zamanımın büyük bir kısmını öğrenmek amacıyla araştırma yapmaya } \\
\text { harcamak hoşuma gider. }\end{array}$ & & 0,614 & & \\
\hline \multirow{6}{*}{ 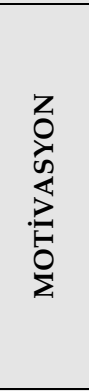 } & 5. Sürekli yeni şeyler öğrenmek benim için bir tutkudur. & & & 0,767 & \\
\hline & $\begin{array}{l}\text { 1. Kendimi geliştirmek için farklı alanlarda yeni bilgi ve beceriler geliştirmek } \\
\text { tam bana göredir. }\end{array}$ & & & 0,737 & \\
\hline & $\begin{array}{l}\text { 3.Yaşamdaki öncelikli hedeflerimden birisi de sürekli yeni bilgi ve beceriler } \\
\text { kazanarak kişisel gelişimimi sağlamaktır. }\end{array}$ & & & 0,724 & \\
\hline & $\begin{array}{l}\text { 2.Kişisel gelişimimi sağlayacağına inanırsam her türlü bilgiyi kolaylıkla } \\
\text { öğrenebilirim. }\end{array}$ & & & 0,592 & \\
\hline & 6.Yeni bilgi ve beceriler öğrenme konusunda arkadaşlarımdan daha istekliyim. & & & 0,572 & \\
\hline & $\begin{array}{l}\text { 4. Yeterli maddi olanaklara sahip olsam da, kişisel gelişimim için yeni bilgi ve } \\
\text { beceriler kazanmaya devam ederim. }\end{array}$ & & & 0,484 & \\
\hline \multirow{11}{*}{ 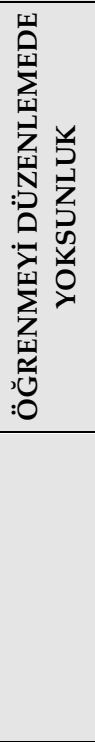 } & $\begin{array}{l}\text { 14. Sadece kişisel gelişimimi sağlamak için sürekli yeni bilgi ve beceriler } \\
\text { kazanmak bana anlamsız gelir. }\end{array}$ & & & & 0,767 \\
\hline & $\begin{array}{l}\text { 13. Mesleğimle ilgili olmayan konularda yeni bilgi ve beceriler kazanmanın bana } \\
\text { yararı olacağına inanmam. }\end{array}$ & & & & 0,685 \\
\hline & 15. Çevremdekilerin öğrenme sürecime yapacakları katkıları önemsemem. & & & & 0,674 \\
\hline & $\begin{array}{l}\text { 18. Öğrendiklerimle ilgili olarak kendi kendimi değerlendirmem yeni konuları } \\
\text { öğrenmeme engel olur. }\end{array}$ & & & & 0,642 \\
\hline & $\begin{array}{l}\text { 16. Zorunlu haller dışında mesleğimle ilgili bilgi kaynaklarını (kitap, internet } \\
\text { vb) kullanmam. }\end{array}$ & & & & 0,532 \\
\hline & $\begin{array}{l}\text { 17. Mesleğimle ilgili yeni karşılaştığım bir bilgi veya beceriyi öğrenmekte } \\
\text { zorlanacağımı düşünüyorum. }\end{array}$ & & & & 0,448 \\
\hline & Cronbach's Alpha & 0,874 & 0,839 & 0,836 & 0,817 \\
\hline & Özdeğer & 8,335 & 3,373 & 1,463 & 1,130 \\
\hline & Açıklanan Varyansın Yüzdesi & 33,340 & 13,492 & 5,853 & 4,521 \\
\hline & Toplam Açıklanan Varyans & 33,340 & 46,832 & 52,685 & 57,206 \\
\hline & $\begin{array}{l}\text { Kaiser-Meyer-Olkin Örneklem Ölçümü } \\
\text { Barlett's Test of Sphercicity }\end{array}$ & \multicolumn{3}{|c|}{$\begin{array}{l}\text { Aprox. Chi-Square } \\
\text { Df } \\
\text { Sig. }\end{array}$} & $\begin{array}{r}0,913 \\
3716,029 \\
300 \\
0,000\end{array}$ \\
\hline
\end{tabular}


"Motivasyon" boyutunun güvenilirlik testi sonucunda Cronbach Alpha katsayısının 0,836 olduğu görülmektedir. Dördüncü faktörün tanımladığı fark yüzdesi 4,521 düzeyindedir ve 6 maddeden oluşmaktadır. Bu faktör "öğrenmeyi düzenlemede yoksunluk" olarak adlandırılmıştır. "Öğrenmeyi Düzenlemede Yoksunluk" faktörünün Cronbach Alpha güvenilirlik katsayısının 0,817 olduğu görülmektedir. Yaşam Boyu Öğrenme Eğilimlerini Belirleme Ölçeğinin iç tutarlılık güvenirlik katsayısı ise 0,75 olarak tespit edilmiştir. Hem ölçeğin hem de faktörlerin güvenilirlik katsayılarına bakıldığında ölçeğin ve faktörlerinin yüksek derecede güvenilirliğe sahip olduğu görülmektedir (Ural ve Kılıç, 2006). Yaşam Boyu Öğrenme Eğilimlerini Belirleme Ölçeğinin açımlayıcı faktör analizi sonucunda ortaya çıkan faktörlerin, ölçeğin alındığı çalışmanın (Diker Coşkun, 2009) bulgularıyla benzerlik gösterdiği tespit edilmiştir.

Tablo 2'de katılımcıların Yaşam Boyu Öğrenme Eğilimlerini Belirleme Ölçeğinden elde edilen puanlar yer almaktadır. Katılımcıların Yaşam Boyu Öğrenme Eğilimlerini Belirleme Ölçeğinden alınan puanları incelendiğinde, alınan en düşük puanın 66 ve en yüksek puanın 150 olduğu tespit edilmiştir. Ölçeğin ortalaması ise 116,05 olarak hesaplanmıştır. Katılımcıların Yaşam Boyu Öğrenme Eğilimlerini Belirleme Ölçeğinden aldıkları puanların ortalaması Diker Coşkun (2009) tarafından belirlenen ortanca puanın üstündedir (25 (iki ifade faktör analizi sonucu ölçekten çıkarılmıştır) x 3,5=87,5<116,05). Bu sonuç turizm rehberliği bölümü öğrencilerinin yaşam boyu öğrenme eğilimlerinin yüksek olduğunu göstermektedir. Yaşam boyu öğrenme eğilimlerini belirleme ölçeğinin faktörlerine ilişkin puanlar incelendiğinde ise katılımcıların motivasyon puanları ortalaması 31,39 olarak hesaplanmıştır. Motivasyon puanları ortalamasının ortanca puanının üstünde olduğu görülmektedir $(31,39>21$ (6 X 3,5). Katılımciların sebat puanları ortalaması 28,05'dir. Sebat puanları ortalamasının ortanca puanının üstünde olduğu görülmektedir (28,05> 21 (6 X 3,5). Katılımcıların öğrenmeyi düzenlemede yoksunluk puanları ortalaması 27,41'dir. Öğrenmeyi düzenlemede yoksunluk puanları ortalamasının ortanca puanının üstünde olduğu görülmektedir $(27,41>21$ (6 X 3,5). Katılımcıların merak yoksunluğu puanları ortalaması 29,18'dir. Merak yoksunluğu puanları ortalamasının ortanca puanının üstünde olduğu görülmektedir $(29,18>24,5(7 \times 3,5)$.

Tablo 2. Yaşam Boyu Öğrenme Eğilimlerini Belirleme Ölçeğinden Elde Edilen Puanlar

\begin{tabular}{|l|c|c|c|c|c|}
\hline Yaşam Boyu Öğrenme Eğilimlerini Belirleme Ölçeği & $\mathbf{n}$ & $\mathbf{M i n}$. & Max. & $\bar{X}$ & SS \\
\hline TOPLAM ÖLÇEK & 323 & 66 & 150 & 116,05 & 19,77 \\
\hline 1. Faktör Motivasyon & 323 & 12 & 36 & 31,39 & 4,12 \\
\hline 2. Faktör Sebat & 323 & 8 & 36 & 28,05 & 5,38 \\
\hline 3. Faktör Öğrenmeyi Düzenlemede Yoksunluk & 323 & 8 & 36 & 27,41 & 7,05 \\
\hline 4. Faktör Merak Yoksunluğu & 323 & 7 & 42 & 29,18 & 8,83 \\
\hline
\end{tabular}

Not: Yaşam boyu öğrenme eğilimlerini belirleme ölçeğindeki motivasyon ve sebat boyutlarının ifadeleri “Hiç Uymuyor" seçeneğinden "Çok Uyuyor" seçeneğine doğru 1,2,3,4,5,6 şeklinde puanlanırken; öğrenmeyi düzenlemede yoksunluk ve merak yoksunluğu boyutlarının ifadeleri de "Hiç uymuyor" seçeneğinden "Çok uyuyor" seçeneğine doğru 6,5,4,3,2,1 şeklinde puanlanmıştır.

Tablo 3'te öğrencilerin yaşam boyu öğrenme eğilimlerinin cinsiyete göre karşılaştırılmasına ilişkin $t$ testi sonucu yer almaktadır. Tablo 3'e göre katılımcıların cinsiyetleri ile yaşam boyu öğrenme eğilimleri ve faktörleri arasında anlamlı bir farklılık bulunmaktadır ( $\mathrm{p}>0,05)$. Buna göre kadın katılımcıların yaşam boyu öğrenme eğilimleri ortalaması $(120,89)$, erkek katılımcıların ortalamalarından daha yüksektir $(111,74)$. Bununla birlikte kadın katılımcıların yaşam boyu öğrenme eğilimlerini belirleme ölçeğinin faktörlerine (motivasyon, sebat, öğrenmeyi düzenlemede yoksunluk ve merak yoksunluğu) ilişkin ortalamalarının erkek katılımcıların ortalamalarından daha yüksek olduğu görülmektedir. 
Öğrencilerin yaşam boyu öğrenme eğilimlerinin yaşa göre karşılaştırılmasına ilişkin tek yönlü varyans analizi (ANOVA) sonuçlarına göre katılımcıların yaşları ile yaşam boyu öğrenme eğilimleri ve faktörlerinden motivasyon, sebat ve merak yoksunluğu faktörleri arasında anlamlı bir farklılık bulunmamaktadır ( $>0,05)$. Bununla birlikte katılımcıların yaşları ile yaşam boyu öğrenme eğilimleri faktörlerinden öğrenmeyi düzenlemede yoksunluk arasında anlamlı bir farklılık olduğu tespit edilmiştir $(\mathrm{p}=0,004<0,05)$. Ortaya çıan anlamlı farklılığın hangi gruplardan kaynaklandığını belirlemek üzere post-hoc analizleri uygulanmıştır. Farklılığın 1719 yaş ve 20-22 yaş grupları arasında olduğu tespit edilmiştir. Buna göre, 17-19 yaş grubundaki öğrencilerin 20-22 yaş grubundaki öğrencilere göre öğrenmeyi düzenlemedeki yoksunluğu daha azdır. Öğrencilerin yaşam boyu öğrenme eğilimlerinin sınıfa göre karşılaştırılmasına ilişkin tek yönlü varyans analizi (ANOVA) sonuçlarına göre katılımcıların sınıfları ile yaşam boyu öğrenme eğilimleri ve faktörlerinden sebat, öğrenmeyi düzenlemede yoksunluk ve merak yoksunluğu faktörleri arasında anlamlı bir farklılık bulunmamaktadır ( $>0,05)$. Bununla birlikte katılımcıların sınıfları ile yaşam boyu öğrenme eğilimleri faktörlerinden motivasyon arasında anlamlı bir farklılık olduğu görülmektedir ( $\mathrm{p}=0,046<0,05)$. Ortaya çıkan anlamlı farklılığın hangi gruplardan kaynaklandığını belirlemek üzere post-hoc analizleri uygulanmıştır. Farklılığın 1. sınıf ve 3. sınıf arasında olduğu tespit edilmiştir. Buna göre, 1. sınıf öğrencilerin motivasyon puanlarının ortalaması $(31,78)$, 3. sınıf öğrencilerine $(30,13)$, göre daha fazladır.

Tablo 3. Öğrencilerin Yaşam Boyu Öğrenme Eğilimlerinin Cinsiyete Göre Karşılaştırılmasına İlişkin $t$ Testi Sonucu

\begin{tabular}{|c|c|c|c|c|c|c|c|}
\hline & Cinsiyet & $\mathrm{n}$ & $\bar{X}$ & SS & sd & $t$ & p \\
\hline \multirow{2}{*}{ Yaşam Boyu Öğrenme Eğilimi } & Erkek & 171 & 111,74 & 20,09 & \multirow{2}{*}{321} & \multirow{2}{*}{$-4,26$} & \multirow{2}{*}{0,00} \\
\hline & Kadın & 152 & 120,89 & 18,29 & & & \\
\hline & & $\mathbf{n}$ & $\bar{X}$ & SS & sd & $t$ & p \\
\hline \multirow{2}{*}{ Motivasyon } & Erkek & 171 & 30,86 & 4,55 & \multirow{2}{*}{321} & \multirow{2}{*}{$-2,48$} & \multirow{2}{*}{0,01} \\
\hline & Kadın & 152 & 31,99 & 3,49 & & & \\
\hline & & $\mathbf{n}$ & $\bar{X}$ & SS & sd & $t$ & p \\
\hline \multirow{3}{*}{ Sebat } & Erkek & 171 & 27,34 & 5,76 & \multirow{2}{*}{321} & \multirow{2}{*}{$-2,51$} & \multirow{2}{*}{0,01} \\
\hline & Kadın & 152 & 28,84 & 4,81 & & & \\
\hline & & $\mathbf{n}$ & $\bar{X}$ & SS & sd & $t$ & p \\
\hline \multirow{3}{*}{$\begin{array}{c}\text { Öğrenmeyi Düzenlemede } \\
\text { Yoksunluk }\end{array}$} & Erkek & 171 & 26,49 & 7,21 & \multirow{2}{*}{321} & \multirow{2}{*}{$-2,50$} & \multirow{2}{*}{0,01} \\
\hline & Kadın & 152 & 28,45 & 6,73 & & & \\
\hline & & $\mathrm{n}$ & $\bar{X}$ & SS & sd & $t$ & p \\
\hline \multirow{2}{*}{ Merak Yoksunluğu } & Erkek & 171 & 27,03 & 8,64 & \multirow{2}{*}{321} & \multirow{2}{*}{$-4,79$} & \multirow{2}{*}{0,000} \\
\hline & Kadın & 152 & 31,60 & 8,43 & & & \\
\hline
\end{tabular}

Tablo 4'te öğrencilerin yaşam boyu öğrenme eğilimlerinin bölümün seçilmesinde etkili olan duruma göre karşılaştırılmasına ilişkin tek yönlü varyans analizi (ANOVA) sonuçları verilmektedir. Tablo 4'e göre katılımcıların bölümün seçilmesinde etkili olan durumu ile yaşam boyu öğrenme eğilimleri faktörlerinden sebat faktörü arasında anlamlı bir farklılık bulunmamaktadır ( $\mathrm{p}=0,057>0,05)$. Bununla birlikte katılımcıların bölümün seçilmesinde etkili olan durumu ile yaşam boyu öğrenme eğilimleri $(p=0,000<0,05)$, motivasyon $(p=0,001<0,05)$, öğrenmeyi düzenlemede yoksunluk $(p=0,001<0,05)$ ve merak yoksunluğu $(p=0,008<0,05)$ arasında anlamlı bir farklılık olduğu görülmektedir. Ortaya çıkan anlamlı farklılıkların hangi gruplardan kaynaklandığını belirlemek üzere post-hoc analizleri uygulanmıştır. Buna göre bölümünü isteyerek seçen öğrencilerin yaşam boyu öğrenme eğilimi puanlarının $(120,12)$ ve motivasyon puanlarının ortalaması $(32,16)$, bölümünü kısmen isteyerek seçen ve istemeyerek seçen öğrencilerin puanlarının ortalamasına göre daha yüksektir. Ayrıca bölümünü isteyerek 
seçen öğrencilerin öğrenmeyi düzenlemedeki yoksunluğu ve merak yoksunluğu, bölümünü kısmen isteyerek seçen ve istemeyerek seçen öğrencilere göre daha azdır.

Tablo 4. Öğrencilerin Yaşam Boyu Öğrenme Eğilimlerinin Bölümün Seçilmesinde Etkili Olan Duruma Göre Karşılaştııılmasına İlişkin ANOVA Testi Sonucu

\begin{tabular}{|c|c|c|c|c|c|c|}
\hline \multirow{5}{*}{$\begin{array}{l}\text { Yaşam Boyu } \\
\text { Öğrenme } \\
\text { Eğilimi }\end{array}$} & $\begin{array}{c}\text { Bölümün Seçilmesinde } \\
\text { Etkili Olan Durum }\end{array}$ & Siklık & Ortalama & F Değeri & p Değeri & Fark \\
\hline & İsteyerek seçtim & 131 & 120,12 & \multirow{4}{*}{8,759} & \multirow{4}{*}{0,000} & \multirow{4}{*}{$1-2-3$} \\
\hline & İstemeyerek seçtim & 33 & 104,77 & & & \\
\hline & Kısmen isteyerek seçtim & 159 & 115,03 & & & \\
\hline & Toplam & 323 & 116,05 & & & \\
\hline \multirow{5}{*}{ Motivasyon } & & Siklık & Ortalama & F Değeri & p Değeri & Fark \\
\hline & İsteyerek seçtim & 131 & 32,16 & \multirow{4}{*}{6,890} & \multirow{4}{*}{0,001} & \multirow{4}{*}{$1-2-3$} \\
\hline & İstemeyerek seçtim & 33 & 29,32 & & & \\
\hline & Kısmen isteyerek seçtim & 159 & 31,19 & & & \\
\hline & Toplam & 323 & 31,39 & & & \\
\hline \multirow{5}{*}{ Sebat } & & Siklık & Ortalama & F Değeri & p Değeri & Fark \\
\hline & İsteyerek seçtim & 131 & 28,77 & \multirow{4}{*}{2,898} & \multirow{4}{*}{0,057} & \multirow{4}{*}{-} \\
\hline & İstemeyerek seçtim & 33 & 26,42 & & & \\
\hline & Kısmen isteyerek seçtim & 159 & 27,79 & & & \\
\hline & Toplam & 323 & 28,05 & & & \\
\hline \multirow{5}{*}{$\begin{array}{c}\text { Öğrenmeyi } \\
\text { Düzenlemede } \\
\text { Yoksunluk }\end{array}$} & & Siklık & Ortalama & F Değeri & p Değeri & Fark \\
\hline & İsteyerek seçtim & 131 & 28,52 & \multirow{4}{*}{7,107} & \multirow{4}{*}{0,001} & \multirow{4}{*}{$1-2-3$} \\
\hline & İstemeyerek seçtim & 33 & 23,44 & & & \\
\hline & Kısmen isteyerek seçtim & 159 & 27,33 & & & \\
\hline & Toplam & 323 & 27,41 & & & \\
\hline \multirow{5}{*}{$\begin{array}{c}\text { Merak } \\
\text { Yoksunluğu }\end{array}$} & & Siklık & Ortalama & F Değeri & p Değeri & Fark \\
\hline & İsteyerek seçtim & 131 & 30,66 & \multirow{4}{*}{4,924} & \multirow{4}{*}{0,008} & \multirow{4}{*}{$1-2$} \\
\hline & İstemeyerek seçtim & 33 & 25,58 & & & \\
\hline & Kısmen isteyerek seçtim & 159 & 28,71 & & & \\
\hline & Toplam & 323 & 29,18 & & & \\
\hline
\end{tabular}

Tablo 5 'te öğrencilerin yaşam boyu öğrenme eğilimlerinin seçilen bölümden memnun olma durumuna göre karşılaştırılmasına ilişkin tek yönlü varyans analizi (ANOVA) sonuçları verilmektedir. Tablo 5'e göre katılımcların seçilen bölümden memnun olma durumu ile yaşam boyu öğrenme eğilimleri ve tüm faktörleri arasında anlamlı bir farklılık bulunmaktadır $(\mathrm{p}=0,000<0,05)$. Katılımcıların seçilen bölümden memnun olma düzeyleri arttıkça yaşam boyu öğrenme eğilimi, motivasyon ve sebat puanlarının ortalamaları artmakta, öğrenmeyi düzenlemedeki yoksunluğu ve merak yoksunluğu ise azalmaktadır.

Tablo 6'da öğrencilerin yaşam boyu öğrenme eğilimlerinin rehberlik mesleğini yapma düşüncesine göre karşılaştırılmasına ilişkin tek yönlü varyans analizi (ANOVA) sonuçları verilmektedir. Tablo 6'ya göre katılımcıların rehberlik mesleğini yapma düşüncesi ile yaşam boyu öğrenme eğilimleri ve tüm faktörleri arasında anlamlı bir farklılık bulunmaktadır $(p=<0,05)$. Rehberlik mesleğini yapmayı düşünen öğrencilerin yaşam boyu öğrenme eğilimi, motivasyon ve sebat puanları ortalaması, rehberlik mesleğini yapmayı düşünmeyen ve kararsız olan öğrencilerin puanlarının ortalamasına göre daha fazladır. Ayrıca rehberlik mesleğini yapmayı düşünen öğrencilerin, öğrenmeyi düzenlemedeki yoksunluğu ve merak yoksunluğu, rehberlik mesleğini yapmayı düşünmeyen ve kararsız olan öğrencilere göre daha azdır. 
Tablo 5. Öğrencilerin Yaşam Boyu Öğrenme Eğilimlerinin Seçilen Bölümden Memnun Olma Durumuna Göre Karşılaştırılmasına İlişkin ANOVA Testi Sonucu

\begin{tabular}{|c|c|c|c|c|c|c|}
\hline \multirow{7}{*}{$\begin{array}{l}\text { Yaşam Boyu } \\
\text { Öğrenme } \\
\text { Eğilimi }\end{array}$} & $\begin{array}{c}\text { Seçilen Bölümden } \\
\text { Memnun Olma Durumu }\end{array}$ & Siklık & Ortalama & F Değeri & p Değeri & Fark \\
\hline & Hiç memnun değilim & 14 & 102,41 & \multirow{6}{*}{10,937} & \multirow{6}{*}{0,000} & \multirow{6}{*}{$1-2-3-4-5$} \\
\hline & Az memnunum & 41 & 110,59 & & & \\
\hline & Karasızım & 57 & 110,95 & & & \\
\hline & Memnunum & 157 & 116,43 & & & \\
\hline & Çok memnunum & 51 & 129,94 & & & \\
\hline & Toplam & 320 & 116,25 & & & \\
\hline \multirow{7}{*}{ Motivasyon } & & S1klık & Ortalama & F Değeri & p Değeri & Fark \\
\hline & Hiç memnun değilim & 14 & 30,00 & \multirow{6}{*}{5,975} & \multirow{6}{*}{0,000} & \multirow{6}{*}{$1-2-3-4-5$} \\
\hline & Az memnunum & 41 & 31,31 & & & \\
\hline & Karasızım & 57 & 30,46 & & & \\
\hline & Memnunum & 157 & 31,19 & & & \\
\hline & Çok memnunum & 51 & 33,81 & & & \\
\hline & Toplam & 320 & 31,44 & & & \\
\hline \multirow{7}{*}{ Sebat } & & Siklık & Ortalama & F Değeri & p Değeri & Fark \\
\hline & Hiç memnun değilim & 14 & 27,22 & \multirow{6}{*}{5,350} & \multirow{6}{*}{0,000} & \multirow{6}{*}{$2-3-4-5$} \\
\hline & Az memnunum & 41 & 26,80 & & & \\
\hline & Karasızım & 57 & 28,03 & & & \\
\hline & Memnunum & 157 & 27,60 & & & \\
\hline & Çok memnunum & 51 & 31,11 & & & \\
\hline & Toplam & 320 & 28,12 & & & \\
\hline \multirow{7}{*}{$\begin{array}{c}\text { Öğrenmeyi } \\
\text { Düzenlemede } \\
\text { Yoksunluk }\end{array}$} & & S1klık & Ortalama & F Değeri & p Değeri & Fark \\
\hline & Hiç memnun değilim & 14 & 22,24 & \multirow{6}{*}{8,937} & \multirow{6}{*}{0,000} & \multirow{6}{*}{$1-2-3-4-5$} \\
\hline & Az memnunum & 41 & 25,33 & & & \\
\hline & Karasızım & 57 & 25,34 & & & \\
\hline & Memnunum & 157 & 28,00 & & & \\
\hline & Çok memnunum & 51 & 31,30 & & & \\
\hline & Toplam & 320 & 27,46 & & & \\
\hline \multirow{7}{*}{$\begin{array}{c}\text { Merak } \\
\text { Yoksunluğu }\end{array}$} & & Siklık & Ortalama & F Değeri & p Değeri & Fark \\
\hline & Hiç memnun değilim & 14 & 22,94 & \multirow{6}{*}{6,959} & \multirow{6}{*}{0,000} & \multirow{6}{*}{$1-2-3-4-5$} \\
\hline & Az memnunum & 41 & 27,14 & & & \\
\hline & Karasızım & 57 & 27,10 & & & \\
\hline & Memnunum & 157 & 29,62 & & & \\
\hline & Çok memnunum & 51 & 33,70 & & & \\
\hline & Toplam & 320 & 29,21 & & & \\
\hline
\end{tabular}

Tablo 7'de öğrencilerin yaşam boyu öğrenme eğilimlerinin iş yaşamında başarılı olunacağına dair inanca göre karşılaştırılmasına ilişkin tek yönlü varyans analizi (ANOVA) sonuçları verilmektedir. Tablo 7'ye göre öğrencilerin iş yaşamında başarılı olunacağına dair inancı ile yaşam boyu öğrenme eğilimleri ve tüm faktörleri arasında anlamlı bir farklılık bulunmaktadır $(\mathrm{p}=<0,05)$. İş yaşamında başarılı olacağına dair inancı olan öğrencilerin yaşam boyu öğrenme eğilimi, motivasyon ve sebat puanları ortalaması, iş yaşamında başarılı olacağına dair inancı olmayan öğrencilerin ve kararsız olan öğrencilerin puanlarının ortalamasına göre daha fazladır. Ayrıca iş yaşamında başarılı olacağına dair inancı olan öğrencilerin öğrenmeyi düzenlemedeki yoksunluğu ve merak yoksunluğu, iş yaşamında başarılı olacağına dair inancı olmayan öğrencilere ve kararsız olan öğrencilere göre daha azdır. 
Tablo 6. Öğrencilerin Yaşam Boyu Öğrenme Eğilimlerinin Rehberlik Mesleğini Yapma Düşüncesine Göre Karşılaştırılmasına İlişkin ANOVA Testi Sonucu

\begin{tabular}{|c|c|c|c|c|c|c|}
\hline \multirow{5}{*}{$\begin{array}{c}\text { Yaşam Boyu } \\
\text { Öğrenme } \\
\text { Eğilimi }\end{array}$} & $\begin{array}{c}\text { Rehberlik Mesleğini Yapma } \\
\text { Düşüncesi }\end{array}$ & Siklık & Ortalama & F Değeri & p Değeri & Fark \\
\hline & Evet & 134 & 121,08 & \multirow{4}{*}{11,343} & \multirow{4}{*}{0,000} & \multirow{4}{*}{$1-2-3$} \\
\hline & Hayır & 66 & 107,44 & & & \\
\hline & Kararsızım & 121 & 115,50 & & & \\
\hline & Toplam & 321 & 116,17 & & & \\
\hline \multirow{5}{*}{ Motivasyon } & & Siklık & Ortalama & F Değeri & p Değeri & Fark \\
\hline & Evet & 134 & 32,43 & \multirow{4}{*}{10,238} & \multirow{4}{*}{0,000} & \multirow{4}{*}{$1-2-3$} \\
\hline & Hayır & 66 & 29,74 & & & \\
\hline & Kararsızım & 121 & 31,24 & & & \\
\hline & Toplam & 321 & 31,43 & & & \\
\hline \multirow{5}{*}{ Sebat } & & Siklık & Ortalama & F Değeri & p Değeri & Fark \\
\hline & Evet & 134 & 29,20 & \multirow{4}{*}{5,316} & \multirow{4}{*}{0,005} & \multirow{4}{*}{$1-2-3$} \\
\hline & Hayır & 66 & 26,91 & & & \\
\hline & Kararsızım & 121 & 27,52 & & & \\
\hline & Toplam & 321 & 28,10 & & & \\
\hline \multirow{5}{*}{$\begin{array}{c}\text { Öğrenmeyi } \\
\text { Düzenlemede } \\
\text { Yoksunluk }\end{array}$} & & Siklık & Ortalama & F Değeri & p Değeri & Fark \\
\hline & Evet & 134 & 28,36 & \multirow{4}{*}{4,416} & \multirow{4}{*}{0,013} & \multirow{4}{*}{$1-2$} \\
\hline & Hayır & 66 & 25,25 & & & \\
\hline & Kararsızım & 121 & 27,61 & & & \\
\hline & Toplam & 321 & 27,44 & & & \\
\hline \multirow{5}{*}{$\begin{array}{c}\text { Merak } \\
\text { Yoksunluğu }\end{array}$} & & Siklık & Ortalama & F Değeri & p Değeri & Fark \\
\hline & Evet & 134 & 31,08 & \multirow{4}{*}{9,134} & \multirow{4}{*}{0,000} & \multirow{4}{*}{$1-2-3$} \\
\hline & Hayır & 66 & 25,52 & & & \\
\hline & Kararsızım & 121 & 29,12 & & & \\
\hline & Toplam & 321 & 29,20 & & & \\
\hline
\end{tabular}

Tablo 7. Öğrencilerin Yaşam Boyu Öğrenme Eğilimlerinin İş Yaşamında Başarılı Olunacağına Dair İnanca Göre Karşılaştırılmasına İlişkin ANOVA Testi Sonucu

\begin{tabular}{|c|c|c|c|c|c|c|}
\hline \multirow{5}{*}{$\begin{array}{c}\text { Yaşam Boyu } \\
\text { Öğrenme } \\
\text { Eğilimi }\end{array}$} & $\begin{array}{l}\text { İş Yaşamında Başarılı } \\
\text { Olunacağına Dair İnanç }\end{array}$ & Sıklık & Ortalama & F Değeri & p Değeri & Fark \\
\hline & Evet & 207 & 121,09 & \multirow{4}{*}{23,548} & \multirow{4}{*}{0,000} & \multirow{4}{*}{$1-2-3$} \\
\hline & Hayır & 23 & 99,44 & & & \\
\hline & Kararsızım & 92 & 109 & & & \\
\hline & Toplam & 322 & 116,09 & & & \\
\hline \multirow{5}{*}{ Motivasyon } & & Sıklık & Ortalama & F Değeri & p Değeri & Fark \\
\hline & Evet & 207 & 32,39 & \multirow{4}{*}{20,083} & \multirow{4}{*}{0,000} & \multirow{4}{*}{$1-2-3$} \\
\hline & Hayır & 23 & 28,33 & & & \\
\hline & Kararsızım & 92 & 29,95 & & & \\
\hline & Toplam & 322 & 31,40 & & & \\
\hline \multirow{5}{*}{ Sebat } & & S1klık & Ortalama & F Değeri & p Değeri & Fark \\
\hline & Evet & 207 & 29,20 & \multirow{4}{*}{14,090} & \multirow{4}{*}{0,000} & \multirow{4}{*}{$1-2-3$} \\
\hline & Hayır & 23 & 25,60 & & & \\
\hline & Kararsızım & 92 & 26,12 & & & \\
\hline & Toplam & 322 & 28,06 & & & \\
\hline \multirow{5}{*}{$\begin{array}{c}\text { Öğrenmeyi } \\
\text { Düzenlemede } \\
\text { Yoksunluk }\end{array}$} & & S1klık & Ortalama & F Değeri & p Değeri & Fark \\
\hline & Evet & 207 & 28,73 & \multirow{4}{*}{14,225} & \multirow{4}{*}{0,000} & \multirow{4}{*}{$1-2-3$} \\
\hline & Hayır & 23 & 21,73 & & & \\
\hline & Kararsızım & 92 & 25,92 & & & \\
\hline & Toplam & 322 & 27,43 & & & \\
\hline \multirow{5}{*}{$\begin{array}{c}\text { Merak } \\
\text { Yoksunluğu }\end{array}$} & & Siklık & Ortalama & F Değeri & p Değeri & Fark \\
\hline & Evet & 207 & 30,75 & \multirow{4}{*}{11,017} & \multirow{4}{*}{0,000} & \multirow{4}{*}{$1-2-3$} \\
\hline & Hayır & 23 & 23,75 & & & \\
\hline & Kararsızım & 92 & 27,00 & & & \\
\hline & Toplam & 322 & 29,18 & & & \\
\hline
\end{tabular}




\section{SONUÇ VE ÖNERILER}

Turizm rehberliği eğitimi alan öğrencilerin yaşam boyu öğrenme eğilimlerinin belirlenmesinin amaçlandığı bu çalışmada Diker Coşkun (2009) tarafından geliştirilen Yaşam Boyu Öğrenme Eğilimlerini Belirleme Ölçeğinden yararlanılmış ve araştırmada açımlayıcı faktör analizi sonucunda ortaya çıkan faktörlerin, ölçeğin alındığı çalışmanın (Diker Coşkun, 2009) bulgularıyla benzerlik gösterdiği ve dört faktör yapısının korunduğu tespit edilmiştir. Araştırmada turizm rehberliği eğitimi alan öğrencilerin yaşam boyu öğrenme eğilimlerini belirleme ölçeğinden elde edilen puanların ortalamasının belirlenen ortanca puanın üstünde olduğu saptanmıştır. Bu sonuç turizm rehberliği bölümü öğrencilerinin yaşam boyu öğrenme eğilimlerinin yüksek olduğunu göstermektedir. Karakuş (2013) tarafından meslek yüksekokulu öğrencilerinin yaşam boyu öğrenme yeterliklerinin belirlenmesine yönelik yapılan çalışmada, öğrencilerin yaşam boyu öğrenme yeterliklerinin iyi seviyede olduğu saptanmıştır. Horuz (2017) tarafından yapılan çalışmada ise mesleki eğitim merkezi öğrencilerinin yaşam boyu öğrenme eğilimlerinin yüksek olduğu ortaya çıkmıştır. Bu çalışmaların sonuçlarını desteklemeyen çalışmalar da bulunmaktadır. Örneğin, Diker Coşkun ve Demirel (2012) tarafından yapılan çalışmada üniversite öğrencilerinin yaşam boyu öğrenme eğilimlerinin düşük, benzer şekilde Dikmen ve diğerleri (2016) tarafından hemşirelik öğrencilerinin yaşam boyu öğrenme eğilimlerini incelemek amacıyla yapılan çalışmada da öğrencilerin yaşam boyu öğrenme eğilimlerinin düşük olduğu tespit edilmiştir. Görüldüğü gibi öğrencilerin yaşam boyu öğrenme eğilimlerinin belirlenmesi amacıyla yapılan çalışmalarda farklı sonuçlar ortaya çıkmaktadır. Bu araştırma da ise turizm rehberliği bölümü öğrencilerinin yaşam boyu öğrenme eğilimlerinin yüksek çıkması mesleğin başarılı bir şekilde devam ettirilebilmesi açısından oldukça önemli ve olması gereken bir sonuçtur. Araştırmada ayrıca turizm rehberliği bölümü öğrencilerinin yaşam boyu öğrenme eğilimlerinin tüm faktörlerine yönelik puanlamalarda da olması beklenen yüksek sonuçlar tespit edilmiştir. Buna göre turizm rehberliği bölümü öğrencilerinin yaşam boyu öğrenme eğilimleri faktörlerinden motivasyon ve sebat puanları yüksek, öğrenmeyi düzenleme yoksunluğu ve merak yoksunluğu azdır. Bu durum bireysel ve mesleki açıdan gelişimlerini sağlayıp iyi bir rehber olabilmek için yaşam boyu öğrenmenin gerekliliklerini yerine getirmeleri ve bu motivasyona sahip olmaları gereken turizm rehberliği bölümü öğrencileri için olması gereken ya da beklenen bir durum olarak değerlendirilebilir. Turizm rehberliği bölümü öğrencileri hem öğrencilik dönemlerinde hem de turist rehberi olarak meslek hayatlarına başladıkları ve bu meslekte hizmet etmeye devam ettikleri süre boyunca yaşam boyu öğrenmeyi benimsemek, bununla ilgili her türlü faaliyete ve sürece katılmak durumundadırlar. Bu süreçte istekli ve yüksek motivasyona sahip olmak, yaşam boyu öğrenmede sebat göstermek, öğrenmeyi düzenlemek ve meraklı olmak turizm rehberliği bölümü öğrencileri için çok önemli gerekliliklerdir.

Araştırmada öğrencilerin yaşam boyu öğrenme eğilimlerinin cinsiyete göre karşılaştırılmasına ilişkin yapılan analiz sonucunda cinsiyet ile yaşam boyu öğrenme eğilimleri ve faktörleri arasında anlamlı farklılıkların bulunduğu tespit edilmiştir. Buna göre kadın katılımcıların yaşam boyu öğrenme eğilimleri, erkek katılımclara göre daha yüksektir. Benzer şekilde kadın katılımcıların, erkek katılımcılara göre motivasyon ve sebat puanlarının daha yüksek, öğrenmeyi düzenlemedeki yoksunluğun ve merak yoksunluğunun ise daha az olduğu belirlenmiştir. Benzer şekilde İzci ve Koç (2012), Diker Coşkun ve Demirel (2012) ve Evin Gencel (2013) tarafından yapılan çalışmalarda da kız öğrencilerin yaşam boyu öğrenme eğilimlerinin erkek öğrencilere göre daha yüksek olduğu tespit edilmiştir.

Araştırmada öğrencilerin yaşam boyu öğrenme eğilimlerinin bölümün seçilmesinde etkili olan duruma göre karşılaştırılmasına ilişkin yapılan analiz sonucunda katılımcıların bölümün seçilmesinde etkili olan durumu ile yaşam boyu öğrenme eğilimleri boyutlarından sebat faktörü 
arasında anlamlı bir farklılık bulunmadığı, bununla birlikte katılımcıların bölümün seçilmesinde etkili olan durumu ile yaşam boyu öğrenme eğilimleri, motivasyon, öğrenmeyi düzenlemede yoksunluk ve merak yoksunluğu arasında anlamlı bir farklılık olduğu saptanmıştır. Bölümünü isteyerek seçen öğrencilerin, bölümünü kısmen isteyerek seçen ve istemeyerek seçen öğrencilere göre, yaşam boyu öğrenme eğilimi ve motivasyonu daha yüksek, ayrıca öğrenmeyi düzenlemedeki yoksunluğu ve merak yoksunluğu daha azdır.

Öğrencilerin yaşam boyu öğrenme eğilimlerinin seçilen bölümden memnun olma durumuna, rehberlik mesleğini yapma düşüncesine ve iş yaşamında başarılı olunacağına dair inanca göre karşılaştırılmasına ilişkin yapılan analiz sonucunda tüm değişkenler ile yaşam boyu öğrenme eğilimleri ve tüm faktörleri arasında anlamlı bir farklılık bulunduğu tespit edilmiştir. Yapılan analiz sonuçlarına göre katılımcıların seçilen bölümden memnun olma düzeyleri arttıkça yaşam boyu öğrenme eğilimi, motivasyon ve sebat puanlarının ortalamaları artmakta, öğrenmeyi düzenlemedeki yoksunluğu ve merak yoksunluğu ise azalmaktadır. Rehberlik mesleğini yapmayı düşünen öğrencilerin yaşam boyu öğrenme eğilimi, motivasyon ve sebat puanları ortalamasının, rehberlik mesleğini yapmayı düşünmeyen ve kararsız olan öğrencilerin puanlarının ortalamasına göre daha fazla olduğu, ayrıca rehberlik mesleğini yapmayı düşünen öğrencilerin, öğrenmeyi düzenlemedeki yoksunluğu ve merak yoksunluğu, rehberlik mesleğini yapmayı düşünmeyen ve kararsız olan öğrencilere göre daha az olduğu tespit edilmiştir. Benzer şekilde iş yaşamında başarılı olacağına dair inancı olan öğrencilerin yaşam boyu öğrenme eğilimi, motivasyon ve sebat puanları ortalaması, iş yaşamında başarılı olacağına dair inancı olmayan öğrencilerin ve kararsız olan öğrencilerin puanlarının ortalamasına göre daha fazladır. Ayrıca iş yaşamında başarılı olacağına dair inancı olan öğrencilerin öğrenmeyi düzenlemedeki yoksunluğu ve merak yoksunluğu, iş yaşamında başarılı olacağına dair inancı olmayan öğrencilere ve kararsız olan öğrencilere göre daha azdır.

Araştırmada ortaya çıkan bulgular turizm rehberliği bölümü öğrencilerinin kendilerinden beklenen ve mesleğin gerektirdiği bir eğilim içinde olduklarını göstermektedir. Öğrencilerin bu eğilimi kaybetmemeleri ve meslek hayatları boyunca korumaları, mesleğin başarısı için oldukça önemlidir. Turizm rehberliği bölümü öğrencileri için yaşam boyu öğrenmenin bir yaşam tarzı ya da biçimi olarak benimsenmesi önem arz etmektedir. Bu amaçla üniversitelerde öğrencilere yaşam boyu öğrenmenin teşvik edilmesi ve desteklenmesi, yaşam boyu öğrenmenin benimsenmesi için gerekli ortamların hazırlanması ve olanakların sunulması, yaşam boyu öğrenme becerilerinin kazandırılması amacıyla gerekli çalışmaların yapılması önerilebilir.

\section{KAYNAKÇA}

Adabaş, A. (2016). Bartın Üniversitesi Lisansüstü Eğitim Öğrencilerinin Yaşam Boyu Öğrenmede Anahtar Yeterliklere Sahip Olma Düzeyleri, Yayımlanmamış Yüksek Lisans Tezi, Bartın Üniversitesi Eğitim Bilimleri Enstitüsü, Bartın.

Aksoy, M. (2008). Hayat Boyu Öğrenme ve Kariyer Rehberliği İlkelerinin İstihdam Edilebilirliğe Etkileri: Otel İşletmeleri Üzerine Bir Uygulama, Yayımlanmamış Doktora Tezi, Gazi Üniversitesi Sosyal Bilimler Enstitüsü, Ankara

Altunışık, R., Coşkun, R., Bayraktaroğlu, S. ve Yıldırım, E. (2004). Sosyal Bilimlerde Araştırma Yöntemleri: SPSS Uygulamalı, 3. Baskl, Avc1 Ofset, İstanbul.

Arslan, Ş. F., Sarıkaya, Ö. ve Vatansever, K. (2016). Yaşam Boyu Öğrenme Eğilimi Ölçeğinin Tıp Eğitimi Alanı İçin Geçerlik ve Güvenirlik Çalışması, Tıp Eğitimi Dünyası, (47), 38-46. 
Aspin, D. N. (2000). Lifelong Learning: Consepts and Conseptions. International Journal of Lifelong Education, 19(1), 2-19.

Atacanlı, M. F. (2007). Ankara Üniversitesi Tıp Fakültesi Öğrencilerinin Öğrenme Tercihi Değerlendirme (LPA) Ölçeği Aracılığıyla Yaşam Boyu Öğrenme Davramışının Yillara Göre Değişiminin Araştırılması, Yayımlanmamış Yüksek Lisans Tezi, Ankara Üniversitesi Sağlık Bilimleri Enstitüsü, Ankara

Avcıkurt, C. (2017). Turizm Sosyolojisi. Ankara: Detay Yayıncılık.

Ayaz, C. (2016). Öğretmenlerin Yaşam Boyu Öğrenme Ĕ̆ilimlerinin Bazı Değişkenler Açısından İncelenmesi (Mardin İli Örneği), Yayımlanmamış Yüksek Lisans Tezi, Bartın Üniversitesi Eğitim Bilimleri Enstitüsü, Yaşam Boyu Öğrenme Anabilim Dalı, Bartın.

Ayra, M. ve Kösterelioğlu, İ. (2015). Öğretmenlerin Yaşam Boyu Öğrenme Eğilimlerinin Mesleki Öz Yeterlik Algıları ile İlişkisi. NWSA Education Sciences, 1 (10), 17-28.

Boztepe, Ö. (2017). Öğretmen Adaylarının Yaşam Boyu Öğrenme ve İletişim Memnuniyet Düzeylerinin İncelenmesi, Yayımlanmamış Yüksek Lisans Tezi, Sakarya Üniversitesi Eğitim Bilimleri Enstitüsü, Sakarya.

Çam, E. ve Üstün, A. (2016). Öğretmenlerin Mesleki Tutumları ile Yaşam Boyu Öğrenme Eğilimleri Arasındaki İlişkisi, Hitit Üniversitesi Sosyal Bilimler Enstitüsü Dergisi, 9 (1), 461-477.

Değirmencioğlu, A. Ö. (1998). Türkiye'de Turizm Rehberlĭğ Eğitimine Bir Yaklaşım, Yayımlanmamış Yüksek Lisans Tezi, Gazi Üniversitesi Sosyal Bilimler Enstitüsü, Ankara

Diker Coşkun, Y. (2009). Üniversite Öğrencilerinin Yaşam Boyu Öğrenme Ĕğilimlerinin Bazı Değişkenler Açısından İncelenmesi, Yayımlanmamış Doktora Tezi, Hacettepe Üniversitesi Sosyal Bilimler Enstitüsü, Ankara.

Diker Coşkun, Y. ve Demirel, M. (2012). Üniversite Öğrencilerinin Yaşam Boyu Öğrenme Eğilimleri. Hacettepe Üniversitesi Ĕ̆itim Fakültesi Dergisi (42), 108-120.

Dikmen, Y., Denat, Y., Filiz N. Y. ve Başaran, H. (2016). Hemşirelik Öğrencilerinde Yaşam Boyu Öğrenme Eğilimleri, Journal of Human Rhythm, 2 (1): 22-26.

Dunlap, J. C., and Grabinger, S. (2003). Preparing Students for Lifelong Learning: A Review of Instructional Features and Teaching Methodologies. Performance Improvement Quaerterly, 16(2), 625.

Erdamar, G. (2011). Yaşam Boyu Öğrenme. Ö. Demirel içinde, Eğitimde Yeni Yönelimler (s. 219-237). Ankara: Pegem Akademi.

Evin Gencel, İ. (2013). Öğretmen Adaylarının Yaşam Boyu Öğrenme Yeterliklerine Yönelik Algiları. Ĕ̆itim ve Bilim, 28 (170), 237-252.

European Commission. (2002). European Report on Quality Indicators of Lifelong Learning. Brussels: European Commission, Directorate-General for Education and Culture.

Güleç, İ., Çelik, S. ve Demirhan, B. (2012). Yaşam Boyu Öğrenme Nedir? Kavram ve Kapsamı Üzerine Bir Değerlendirme. Sakarya Üniversitesi Ĕ̆itim Fakültesi Dergisi, 3 (2), 34-48.

Günüç, S., Odabaşı, F. ve Kuzu, A. (2012). Yaşam Boyu Öğrenmeyi Etkileyen Faktörler. Gaziantep Üniversitesi Sosyal Bilimler Dergisi, 11 (2), 209-325.

Gür Erdoğan, D. (2014). Öğretmen Adaylarının Yaşam Boyu Öğrenme Ĕ̆gilimlerine Etki Eden Faktörler, Yayımlanmamış Doktora Tezi, Abant İzzet Baysal Üniversitesi Eğitim Bilimleri Enstitüsü, Bolu. 
Goverment of Irland. (2000). Learning for Life: White Paper on Adult Education. Dublin: Goverment of Irland Department of Education and Science.

Haseski, H. İ., Şahin, Y. L., Yılmaz, E. ve Erol, O. (2014). Facebook Kullanım Amaçları İle Yaşamboyu Öğrenme Eğilimleri Arasındaki İlişkinin İncelenmesi, Eğitimde Kuram ve Uygulama, $10(2), 331-351$.

Horuz, O. R. (2017). Mesleki Eğitim Merkezi Öğrencilerinin Yaşam Boyu Öğrenme Eğilimlerinin İncelenmesi (Bartın İli Örneği), Yayımlanmamış Yüksek Lisans Tezi, Bartın Üniversitesi Eğitim Bilimleri Enstitüsü, Bartın.

İzci, E. ve Koç, S. (2012). Öğretmen Adaylarının Yaşam Boyu Öğrenmeye İlişkin Görüşlerinin Değerlendirilmesi, Adryaman Üniversitesi Sosyal Bilimler Enstitüsü Dergisi, 5 (9): 101-114.

Kangalgil, M. ve Özgül, F. (2018). Türkiye'de Beden Eğitimi ve Spor Eğitimi Alan Öğrencilerin Yaşam Boyu Öğrenme Eğilimlerinin İncelenmesi. Journal of Global Sport and Education Research, 1 (1), 64-72.

Karakuş, C. (2013). Meslek Yüksek Okulu Öğrencilerinin Yaşam Boyu Öğrenme Yeterlikleri. Eğitim ve Öğretim Araştırmaları Dergisi, 2 (3), 26-35.

Kozikoğlu, İ. (2014). Üniversite Meslek Yüksekokulu Öğrencilerinin Yaşam Boyu Öğrenme Yeterliklerinin İncelenmesi. Eğitim Teknolojileri ve Öğretmen Eğitimi Dergisi, 3 (3), 29-43.

Mülhim, M. A. (2018). Beden Eğitimi ve Spor Yüksekokulu Öğrencilerinin Bireysel Yenilikçilik Düzeyleri ve Yaşam Boyu Öğrenme Eğilimlerinin İncelenmesi: Bartın Üniversitesi Örneği, Yayımlanmamış Yüksek Lisans Tezi, Bartın Üniversitesi Eğitim Bilimleri Enstitüsü, Bartın.

Samancı, O. ve Ocakcı, E. (2017). Hayat Boyu Öğrenme. Bayburt Ĕ̆gitim Fakültesi Dergisi, 12 (24), 711-722.

Sarıgöz, O. (2015). Meslek Yüksekokulu Öğrencilerinin Yaşam Boyu Öğrenme Yaklaşımına İlişkin Görüş ve Farkındalıklarının Değerlendirilmesi, Yayımlanmamış Doktora Tezi, Yakın Doğu Üniversitesi Eğitim Bilimleri Enstitüsü, Lefkoşa.

Temizkan, R. (2005). Turist Rehberlerinin Türkiye İmajını Algılamaları, Yayımlanmamış Yüksek Lisans Tezi, Mustafa Kemal Üniversitesi Sosyal Bilimler Enstitüsü, Hatay.

Tetik, N. (2012). Turist Rehberlerinin Ekoturizm Alanındaki Yeterlilikleri: Doğu Karadeniz Örneği, Yayımlanmamış Doktora Tezi, Balıkesir Üniversitesi Sosyal Bilimler Enstitüsü, Balıkesir.

Tuschling, A., and Engemann, C. (2006). From Education to Lifelong Learning: The Emerging Regime of Learning in The European Union. Educational Philosophy and Theory, 38(4), 451-469.

Ural, A. ve Kılıç, İ. (2006). Bilimsel Araştırma Süreci ve Spss ile Veri Analizi SPSS 10.0-12.0 for Windows, 2. Baskı, Ankara: Detay Yayıncılık.

Üzümcü, T. P., Alyakut, Ö. ve Günsel, A. (2015). Turizm Eğitimi Alan Öğrencilerin, Mesleğin Geleceğine İlişkin Bakış Açıları. Balıkesir Üniversitesi Sosyal Bilimler Enstitüsü Dergisi, 18(33), 179199.

Yaman, F. (2014). Öğretmenlerin Yaşam Boyu Öğrenme Eğilimlerinin İncelenmesi (Diyarbakır İli Örneği), Yayımlanmamış Yüksek Lisans Tezi, Dicle Üniversitesi Eğitim Bilimleri Enstitüsü, Diyarbakır.

Yılmaz, R. ve Beşkaya, Y. M. (2018). Eğitim Yöneticilerinin Yaşam Boyu Öğrenme Eğilimleri ile Bireysel Yenilikçilik Düzeylerinin İncelenmesi, Ankara Üniversitesi Eğitim Bilimleri Fakültesi Dergisi, 51 (1), 159-181 